\title{
Krónikus parodontitis komplex parodonto-endo-protetikai kezelése
}

\author{
DR. PILIHACI BELLA, DR. GERA ISTVÁN
}

\begin{abstract}
A krónikus parodontitis hagyományos mechanikai tisztításra és oki parodontális sebészi kezelésre jól reagál. Ma a krónikus parodontitis terápiás protokollja ismert és tudományosan igazolt. A kezelés két nagy fázisra, az iniciális vagy oki terápiára és a korrekciós fázisra osztható, ugyanakkor legtöbb esetben a páciensek komplex parodontális, konzerváló és protetikai kezelésre is szorulnak. Egy krónikus parodontitisben szenvedő 55 éves férfibeteg komplex kezelésének menete és eredménye kerül ismertetésre. A betegnek reménytelen prognózisú foga nem volt. Kezelési tervünkben oki parodontális kezelés, azaz professzionális szájhigiénés kezelés, kürettálás, majd sebészi tasakkezelések és végül a protetikai ellátás szerepelt. A supragingivalis szájhigiéniás fázist a nem sebészi tasakkezelés, a kvadránsonként végzett zárt kürett követte. A fázis egy terápia után az újraértékeléskor a mandibuláris két kvadránsban jelentős tasakredukció következett be, azonban a felső fogívben több fogcsoportnál is indikált volt sebészi tasakkezelés, mindkét kvadránsban a szükséges osteoplasticával kísért, módosított Widman-lebenyes mútét történt, melyet a 24, 36 és 47-es fogak régi gyökértömésének revíziója követte. A 24-es fogon a gyulladásos gyökérresorptio miatt a gyökértömés cseréje után gyökércsúcs rezekció mellett döntöttünk. Három hónapot követően üvegszálas csapos csonkkiegészítéssel láttuk el a 24-es fogat. Kilenc hónapot követően a 24-es fog gyökércsúcsa körüli terület radiológiai telődést mutatott. Az 12, 24 és 36-os fogakra supragingivális széli zárású fémkerámia koronák készültek, a 44-47-es pillérfogakra pedig fémkerámia híd. A páciens klinikailag tökéletes szájhigiéniát tart fent, a plakkérték $20 \%$ alatt volt, a vérzési érték $6 \%$-ra csökkent. A parodontális, konzerváló fogászati és protetikai ellátás befejezése után a pácienst 3 havonta visszarendeltük parodontális gondozás céljából.
\end{abstract}

Kulcszó: krónikus parodontitis, nem sebészi tasak-kezelés, parodonto-endo-protetikai kezelés, módosított Widman-lebeny, fenntartó kezelés

\section{Bevezetés}

A fogágybetegség primer oka az érett bakteriális biofilm [8, $17,36,38]$. Alapvetően a biofilm akkumulációra adott szervezeti immunválasz jellege dönti el, hogy milyen mértékủ és formájú pusztulás keletkezik a rögzítő apparátusban. A fogágybetegség leggyakoribb formája a krónikus parodontitis [1, 2], amelyben a progresszió viszonylag lassú, és elég szoros összefüggés van a supragingivális szájhigiénia, a lokális irritatív tényezők és a gyulladás között [24, 37]. A háttérben több ismert rizikófaktor húzódik meg. A legfontosabb magatartási rizikótényező a dohányzás, míg a szisztémás faktorok között leggyakrabban a diabetes szerepel. Ezenfelül több életvitellel összefüggő és szisztémás, részben örökletes oki tényezőt ismerünk. Ennek értelmében a szervezet általános egészségi állapota és bizonyos genetikai tényezők jelentős mértékben befolyásolják a betegség kiterjedését, lefolyását és kezelésének sikerességét [15].

A krónikus parodontitisre jellemző a supra és subgingivális plakk- és fogkő-akkumuláció, az ínyszéli gyulladás, a tasakképződés és tapadásveszteség, amely dominánsan horizontális csontpusztulással társul. A betegség hagyományos mechanikai tisztításra és oki pa- rodontális sebészi kezelésre általában jól reagál. Ma a krónikus parodontitis terápiás protokollja ismert és tudományosan igazolt. A kezelés két nagy fázisra, az iniciális vagy oki terápiára és a korrekciós fázisra osztható $[28,29]$. Az oki kezelés célja a subgingivális dentális biofilm és plakk retenciós tényezők tökéletes eliminációja $[6,7]$.

Az elmúlt évtizedben a sebészi/nem sebészi tasakkezelés hatékonyságát sokan tanulmányozták és több összefoglaló közlemény született [20, 21, 22, 30, 32, $39,40,43]$. Ennek alapján elmondhatjuk, hogy a tasakmélység és a fogak anatómiai tulajdonságai határozzák meg a tasakkezelés technikáját, és a helyesen megválasztott technika sokban hozzájárul a postoperatív eredmények kiszámíthatóságához.

A jól kontrollált klinikai vizsgálatok azt mutatják, hogy egygyökerü fogak körül maximálisan $5 \mathrm{~mm}$ mély parodontális tasakok esetében a nem sebészi tasakkezelés, azaz a subgingivalis depurálás, gyökérsimítás és kürett hatásos és néha végleges terápiás eredményt adhat. Az $5 \mathrm{~mm}$-nél mélyebb tasakok esetében a zárt kürettől végleges, kiszámítható eredményt nem várhatunk, és indokolt a sebészi feltárás. Terápiás szempontból fontos különbséget tenni a moláris fogak furcatio régióit 
érintő és furcatió lézióval nem járó krónikus parodontitis között. A furcatio lézióval nem társuló krónikus parodontitis kezelése sokkal kiszámíthatóbb és ritkábban igényel sebészi feltárást [19, 30].

Azonban alapelvként fogadhatjuk el, hogy minden olyan esetben, amikor a nem sebészi tasakkezelés után nem szűnik meg az ínyvérzés és nem csökkent a szondázási mélység, indokolt a tasak sebészi feltárása és a gyökérfelszín tisztítása [10,11]. A sebészi feltáráskor dönthetünk arról is, hogy a tasak tisztításával együtt a tasakmélységet is csökkentjük az ínylebeny apicalis irányú áthelyezésével, vagy megelégszünk a tasaktisztítással és az ínyszélt eredeti helyére fektetjük vissza. Ezzel jelentős mértékben csökken a patogén subgingivalis tasakflóra újraképződésének esélye, javulnak az egyéni szájhigiéne feltételei és a későbbi professzionális fenntartó kezelés esélyei is [11, 23, 25, 33].

A krónikus parodontitis ma még nem gyógyítható betegség, a horizontális csontpusztulás regeneratív sebészi technikákkal sem korrigálható $[15,16]$. Csupán a gyulladásos folyamat progressziójának megállítására vállalkozhatunk. Akinél egyszer már megindult a tapadásveszteség, mindig lényegesen nagyobb veszélye van annak, hogy az aktív gyulladásos folyamat újra fellángol, mint azoknál, akik ilyen betegségben még soha nem szenvedtek. Ezért ilyen beteg állandó professzionális ellenőrzésre és nagyon gondos helyreállító sebészi és protetikai kezelésre szorul. Bizonyos esetekben a beteg korrekciós mucogingivalis mútétre is szorul. A helyreállító protetikai kezelésre csak a gyulladás teljes megszűnése, és nagyon jó egyéni szájhigiénia mellett kerülhet sor. Figyelembe kell venni azt, hogy az egyszer már parodontitisen átesett beteg mindig is fogékonyabb a betegség aktivizálódására és mindent meg kell tennünk annak érdekében, hogy a fogpótlás ne akadályozza a hatékony fogmosást és a rendszeres professzionális szájhigiéniás kezelést [26, 27]. Kritikus a koronák széli záródása, annak supra- vagy subgingivális elhelyezkedése, a fogközök alakja és a hézagfog kialakítása. Sok vizsgálat igazolta, hogy még a nagyon precíz subgingivalis koronaszél adaptáció mellett is fokozott a sulcus váladék, és a subgingivális baktériumflóra eltolódik az anaerobok irányába [26]. Végül nagyon fontos a protetikai rekonstrukció befejezése után a páciens rendszeres ellenőrzése és ennek során minden alkalommal elvégzett professzionális szájhigiéniás kezelés [18].

Összefoglalva tehát a krónikus parodontitis kezelési protokollja a következő szakaszokra osztható [16]:

1. betegvizsgálat, elsődleges diagnózis, rizikóanalízis, parodontális prognosztika

2. az akut parodontális állapot azonnali ellátása, esetleges extractiók

3. szájhigiéniás motiváció és előzetes instrukciók

4. professzionális supra- és subgingivális depurálás, plakk retenciós tényezők eliminálása, szükség szerint ideiglenes sínezés, okklúziós korrekció
5. nem sebészi tasakkezelés -zárt kürett

6. végleges szájhigiéniás instrukciók

7. első újraértékelés és döntés a sebészi tasakkezelés indikációjáról

8. sebészi tasakkezelés - rezektív vagy nem rezektív tasaksebészet

9. második újraértékelés

10. korrekciós sebészet-mucogingivalis sebészet

11. végleges foganként prognózis-protetikai rehabilitáció 12. fenntartó kezelés

Egy előrehaladott krónikus parodontitises páciens teljes körű kezelése sok esetben egy-másfél évig tart, és nem lehet bizonyos fázisokat lerövidíteni vagy elhagyni [16]. Az alább leírt esetünkben azt kívánjuk bemutatni, hogy egy elörehaladott krónikus parodontitisben szenvedő páciens esetében milyen lépésekben lehetett helyreállítani az egészséges funkciót és esztétikumot és milyen előkészítő beavatkozásokra van szükség ahhoz, hogy jó minőségú és kiszámítható prognózisú végleges fogpótlások készüljenek.

\section{Esetismertetés}

Az 55 éves férfi pácienst fogorvosa utalta be a Semmelweis Egyetem Parodontológiai Klinikájára. A páciens ínyvérzésről és kellemetlen szájszagról panaszkodott. Az anamnézisben fogászati kezelést befolyásoló általános tényező, dohányzás nem szerepelt. $A$ betegvizsgálat során a sztomato-onkológiai szürés és a TMI analízis eredménye negatív lett. A páciens szájhigiéniája rossz volt, fogait nagy mennyiségú plakk és fogkő borította. Az elálló szélű fogpótlások mentén kifejezett ínygyulladás, helyenként secunder caries volt megfigyelhető (1. $a, b, c, d$, e ábra).

A felvételkor tapasztalt fogászati és parodontális státuszt mutatja a 2. ábra, a tasakmélység (PPD), ínyrecesszió (GR), ínyvérzési (BoP) és plakk ( $\mathrm{PI}$ ) értékeket feltüntetve. A kiindulási radiológiai státuszt a 3. ábra mutatja.

A klinikai és radiológiai vizsgálat alapján reménytelen prognózisú fogat nem találtunk, kérdéses prognózisúnak a 24 és 27 -es fogakat ítéltük, melyeknek sorsáról a kezelés későbbi szakaszában dönthetünk.

A kezelési tervünkben oki parodontális kezelés, azaz professzionális szájhigiénés kezelés, kürettálás, majd sebészi tasakkezelések és végül a protetikai ellátás szerepelt.

A supragingivális szájhigiéniás fázist követően a nem sebészi tasakkezelést, zárt kürettet kvadránsonként, helyi érzéstelenítésben végeztük. A páciensnek antibiotikumot nem rendeltünk. Néhány hónappal később a páciens egyéni szájhigiéniájának és együttműködési készségének értékelésekor $17 \%$-os teljes száj-plakk értéket (FMPS) mértünk, a teljes száj ínyvérzési érték pedig (FMBS) 10\%-ra csökkent. A PPD értékek szintén csökkentek (4. ábra). Az újraértékeléskor a nem sebészi tasakkezelés eredményét figyelembe véve megállapí- 


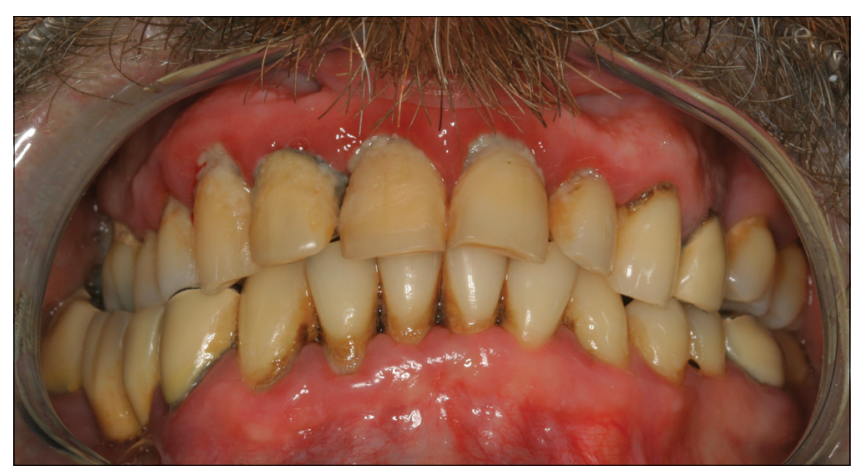

1. ábra: Kiindulási klinikai képek

a) kiindulási kép összezárt helyzetben

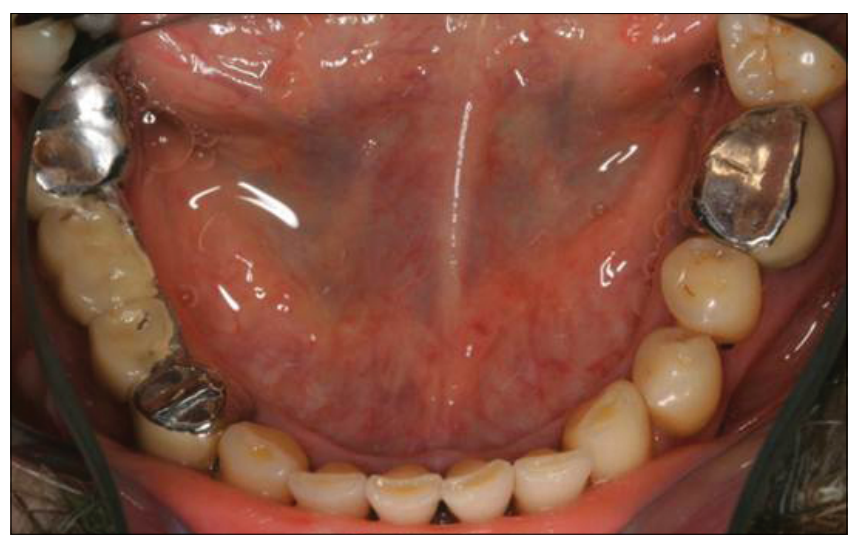

b) alsó fogív

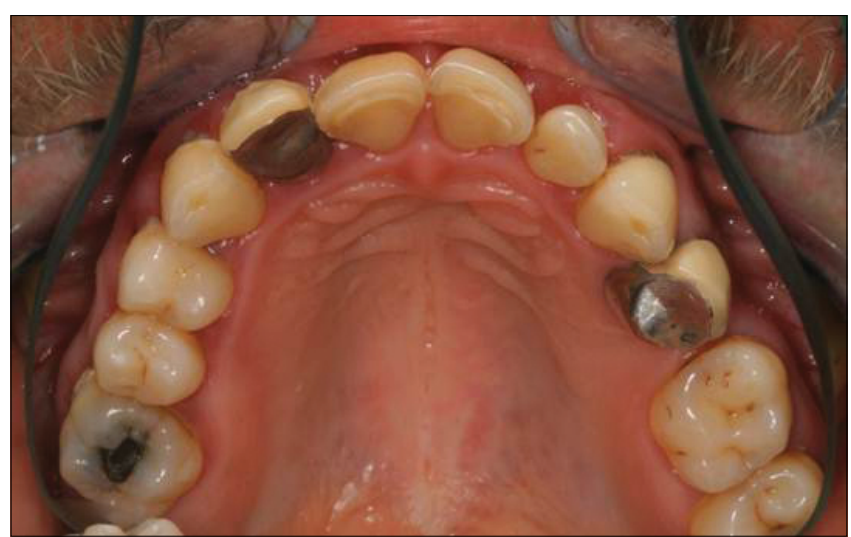

c) felső fogív

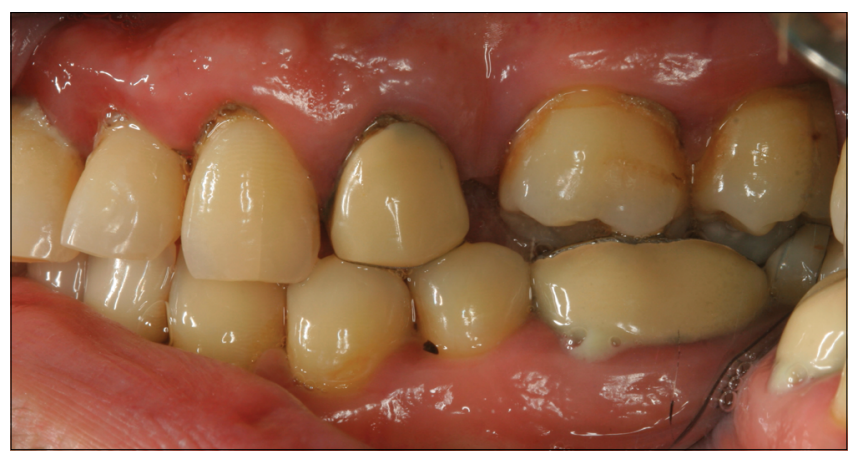

d) bal oldal összezárt helyzetben

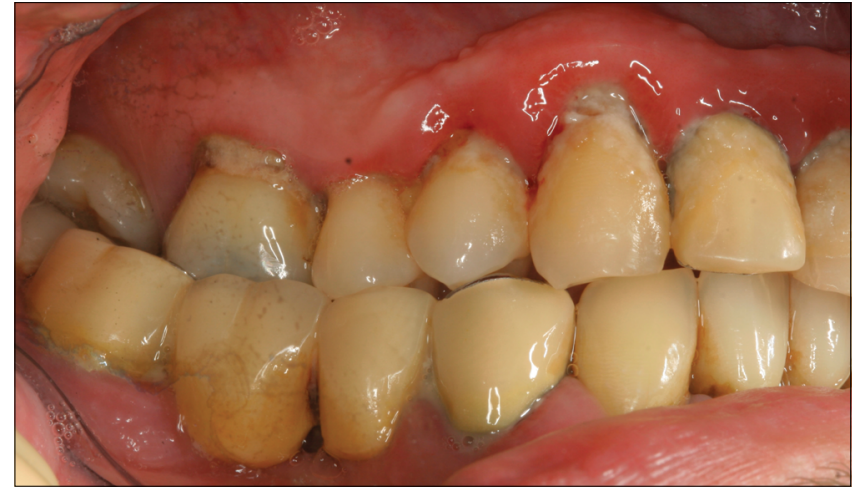

e) jobb oldal összezárt helyzetben

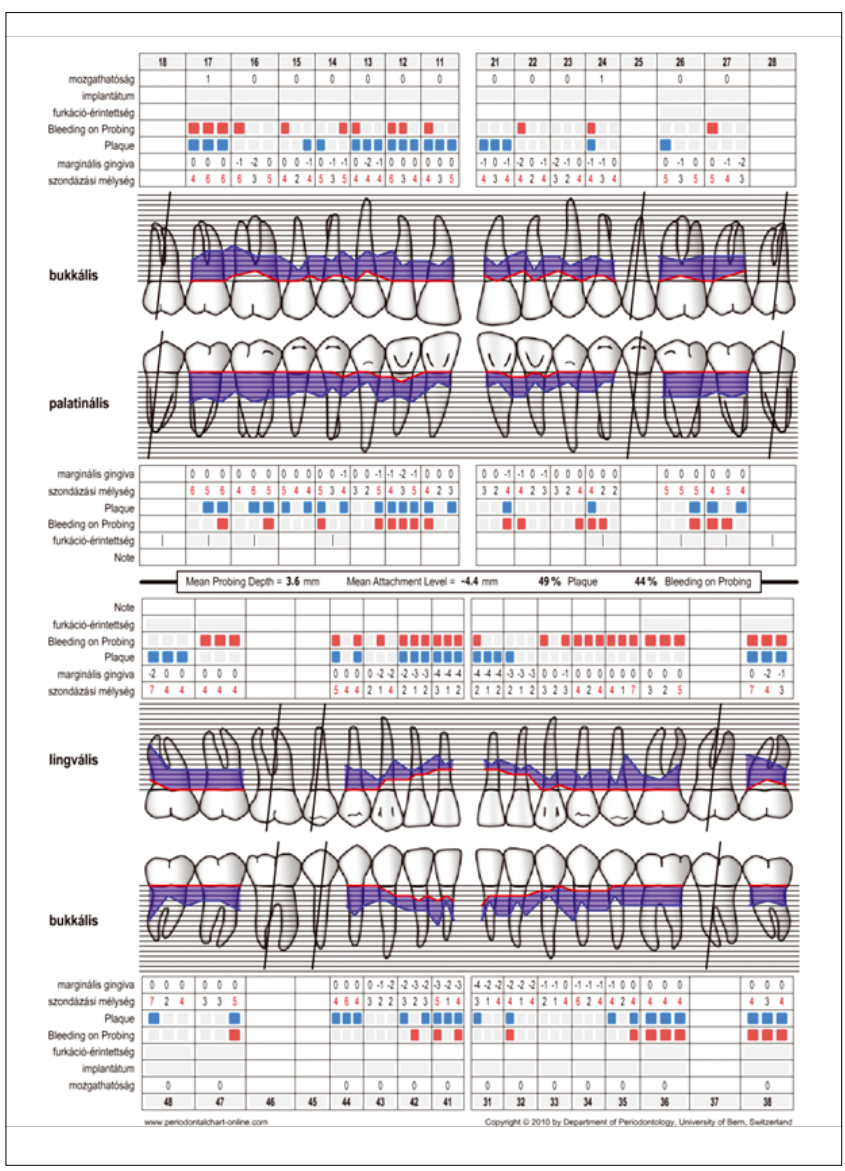

2. ábra: Kiindulási parodontális státusz

tottuk, hogy a mandibuláris két kvadránsban jelentős tasakredukció következett be, ezért itt nem találtuk indokoltnak sebészi tasakkezelést (5. a, b ábra). Ugyanakkor a felső fogívben több fogcsoportnál - tekintettel az újraértékeléskor mért tasakmélység-értékekre és a moláris fogak gyökerének nehezebben elérhető felszíneire - sebészi tasakkezelést indikáltunk. Első lépésben a jobb felső kvadránsban módosított Widmanlebenyes mútétet végeztünk [33], a szükséges osteoplastica után a sebszéleket per primam zártuk (6. $a, b$, $c$ ábra). A mútét után két hétig chlorhexidines szájöblítést rendeltünk. Varratszedéskor zavartalan sebgyógy- 


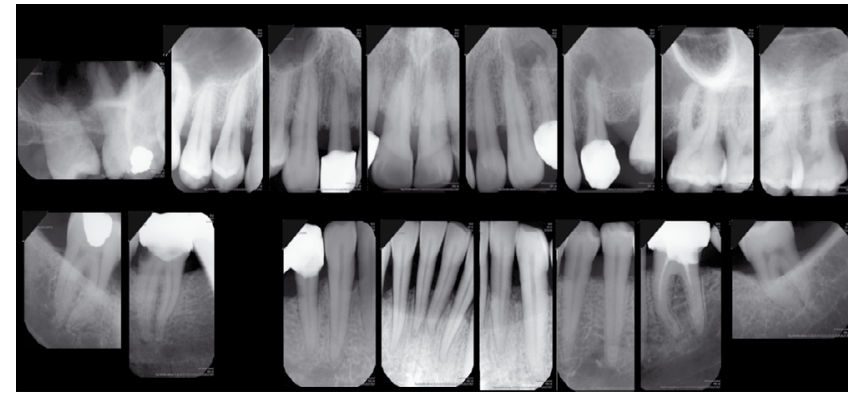

3. ábra: Kiindulási röntgenstátusz (supragingivális depurálást követően)

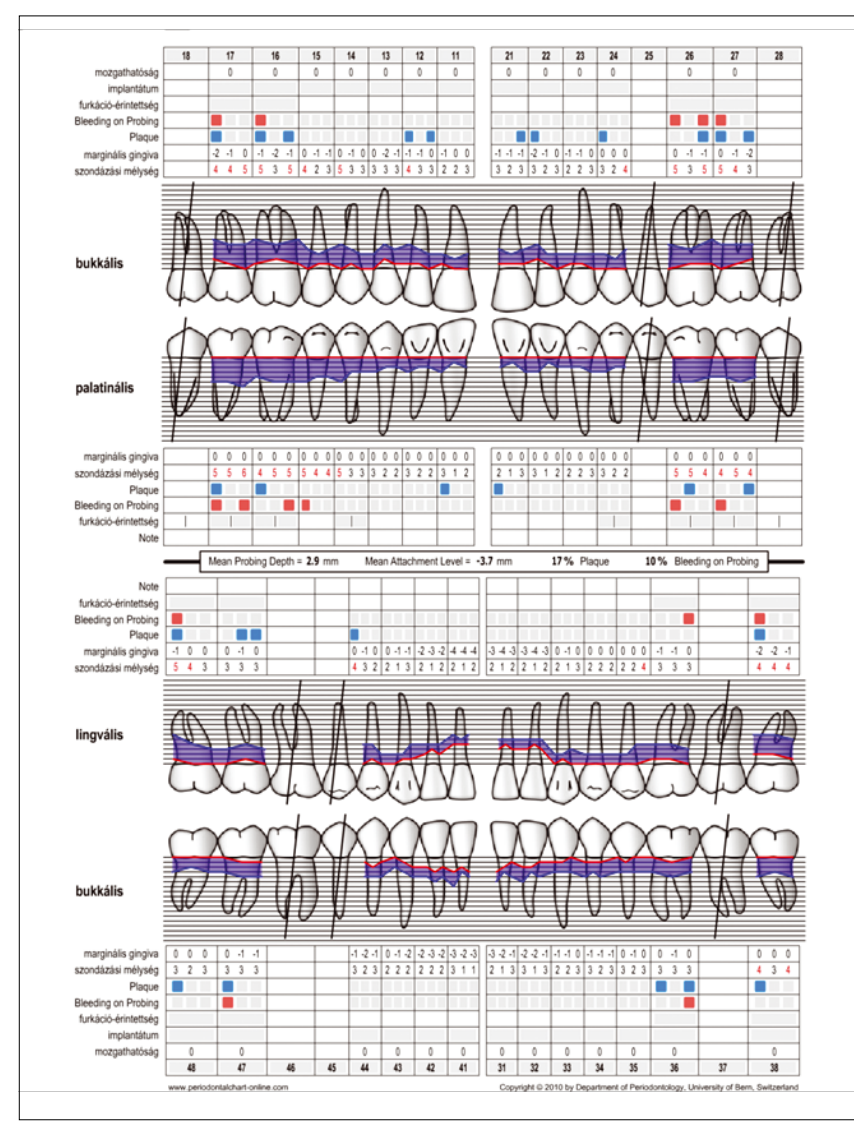

4. ábra: A konzervatív kezelési fázist követő parodontális státusz

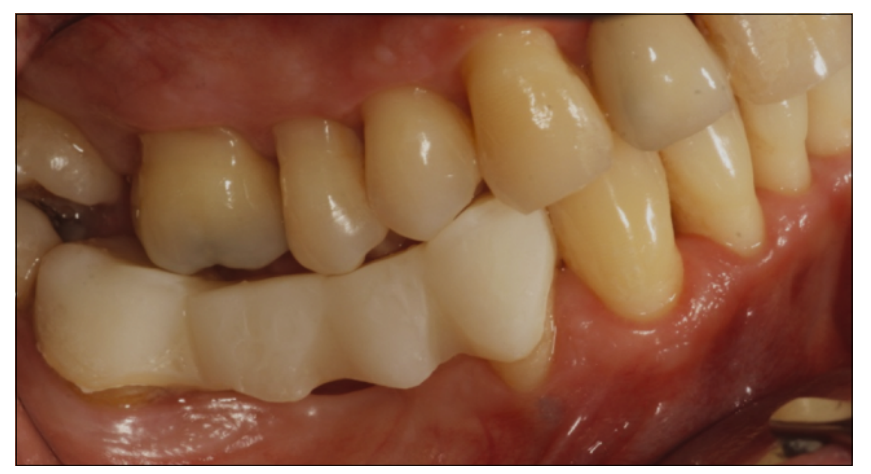

5. ábra: Az alsó kvadránsok klinikai képe konzervatív parodontális kezelést követően a) jobb oldal ulást tapasztaltunk. Az első mútét után 6 héttel került sor a bal felső kvadráns sebészi kezelésére, ahol az elsőhöz hasonlóan Widman-lebenyes mútétet végeztünk, a sebszéleket per primam zártuk (7. a, b ábra). A zavartalan sebgyógyulás után több héttel került sor a konzerváló és endodonciai kezelésekre

Elvégeztük a 24, 36 és 47-es fogak gyökérkezelését, illetve revízióját. A 47-es fogban felfedezett accessoricus csatorna obturációja is megtörtént (8. $a, b$ ábra). A 24-es fogon valószínüleg a periodontitis apicalis chronica következtében kialakult gyulladásos gyökérresorptio miatt a gyökértömés cseréje során az apex egy része levált a gyökérről és a gyökértömő anyag a periapicalis térbe került, ezért a gyökércsúcs-rezekció mellett döntöttünk. A területet Pichler-lebeny képzésével tártuk fel és a rezekciót követően egyszerű csomós öltésekkel zártuk (9. $a, b, c, d$ ábra). A varratszedésre egy héttel a mútétet követően került sor. Három hónap múlva a 24-es fogat üvegszálas csapos csonkkiegészítéssel láttuk el. Kilenc hónapot követően a 24-es fog gyökércsúcsa körüli terület radiológiai telődést mutatott és a páciens panaszmentes volt, ezért elkészítettük a végleges fémkerámia koronát (9. e ábra).

$\mathrm{Az} 12$ és 36-os fogakra vállas preparálás mellett szintén fémkerámia koronák készültek. A 44-47-es fogakra Orton vállas preparálás mellett készült fémkerámia híd, a pillérfogak a 44, 47-es fogak, a hézagfogak 45, 46-os fogak voltak (10. a, b, c, d ábra).

A kiértékelő parodontális státuszon, a terápia befejezését követően fél évvel (11. ábra) jól látható, hogy a plakk-érték továbbra is $20 \%$ alatt volt, a vérzési érték 6\%-ra csökkent, klinikailag a páciens tökéletes szájhigiéniát tart fent, a supragingivális széli záródású koronák/hidak approximális tisztítása is kiváló (12. $a, b, c$, $d$, e ábra). A kezeléseket követően egy évvel később készült kontroll panorámafelvétel és radiológiai státusz készült a páciensről (13. $a, b$ ábra).

A parodontális, konzerváló fogászati és protetikai ellátás befejezése után a pácienst 3 havonta visszarendeljük, mivel gyakori professzionális szájhigiénés kezelés és ismételt instruálás-motiválás egy krónikus parodontitisen átesett páciens esetében elengedhetet-

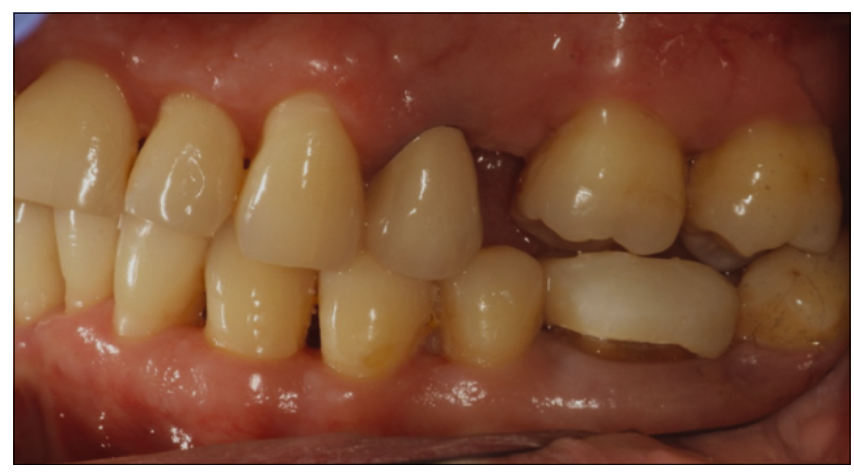

b) bal oldal 


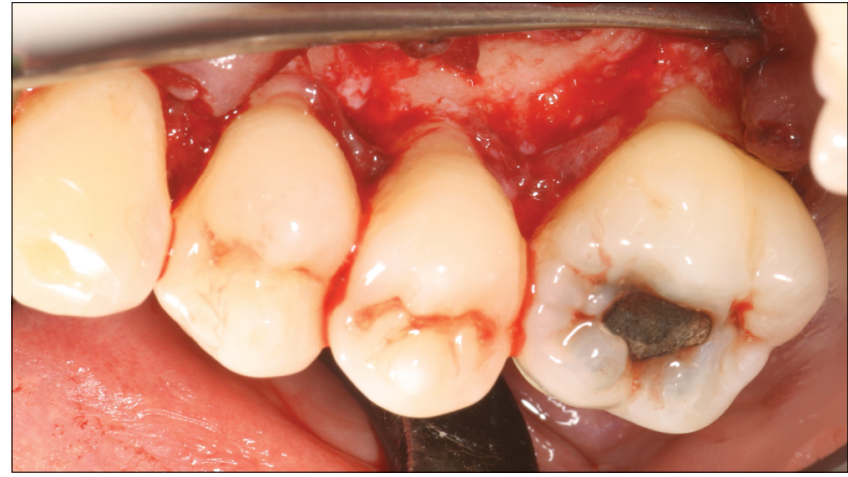

6. ábra: Jobb felső kvadráns sebészi terápia a) intraoperatív kép a lebenyképzést követően

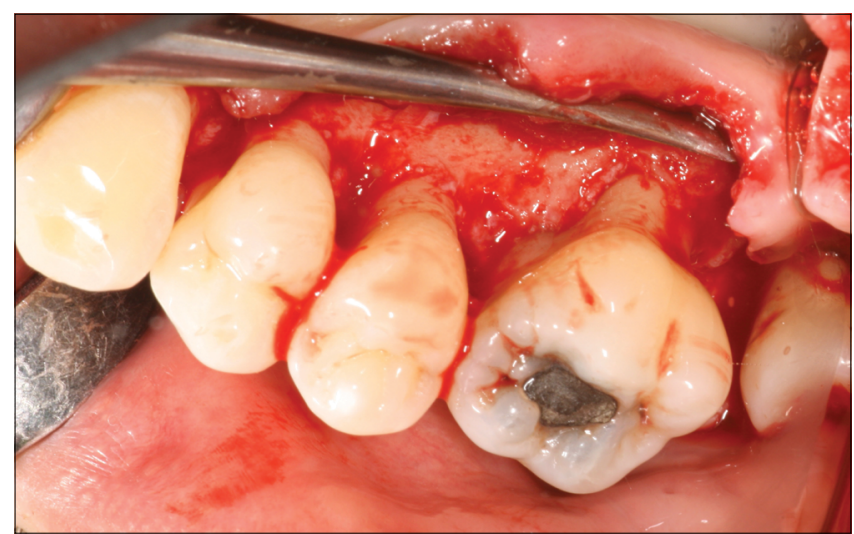

b) intraoperatív kép a kürettálást és gyökérsimítást követően

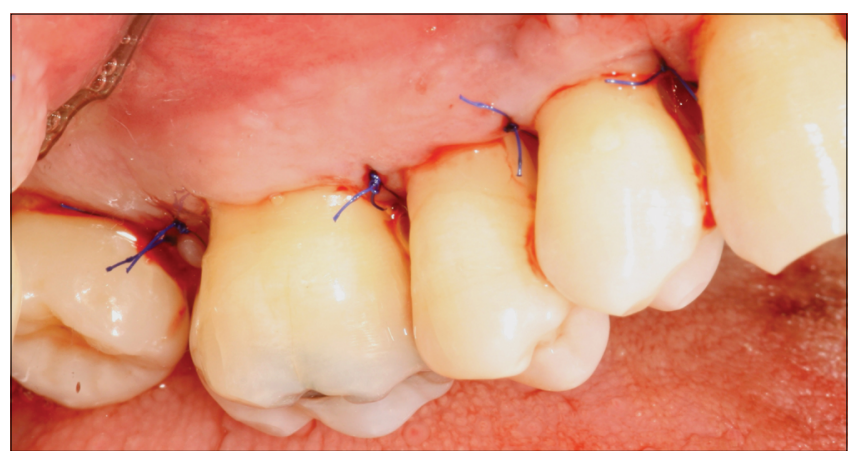

c) per primam sebzárás

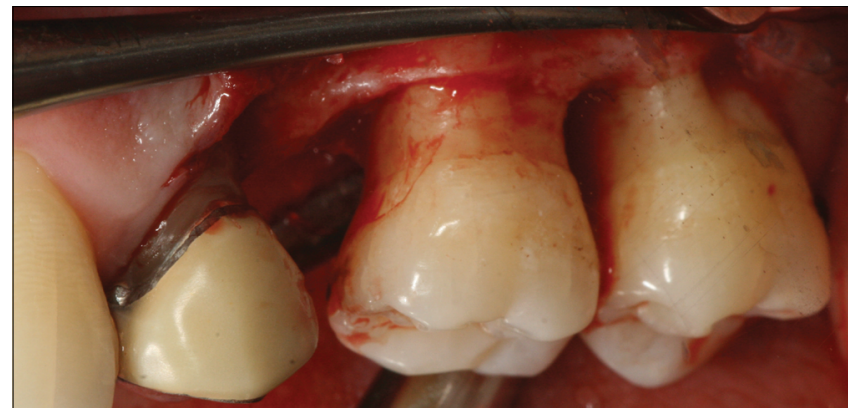

7. ábra: Bal felső kvadráns sebészi terápia a) intraoperatív kép a kürettálást és gyökérsimítást követően

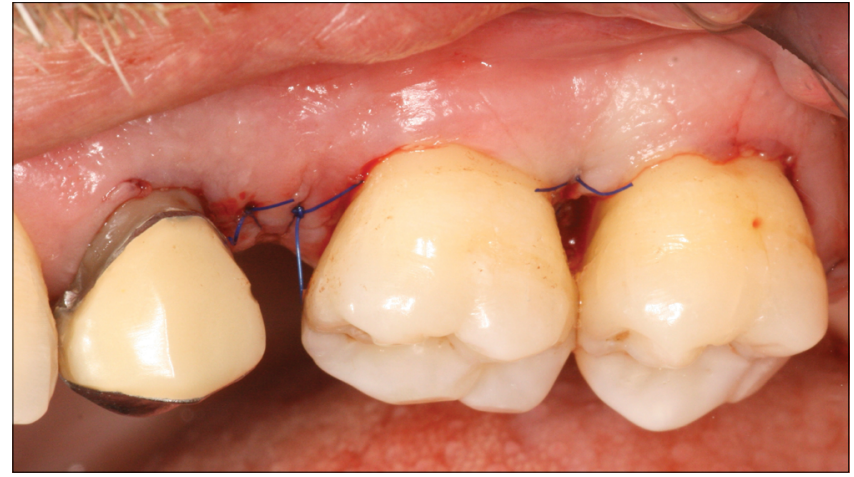

b) per primam sebzárás

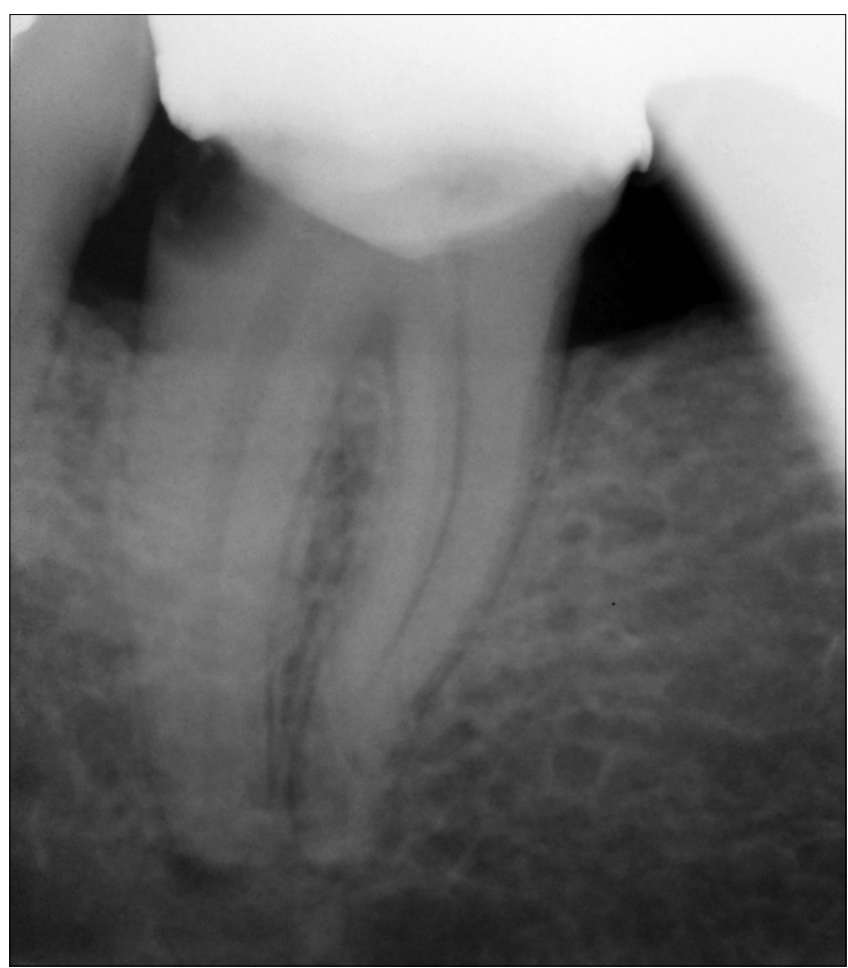

8. ábra: 24, 36 és 47-es fogakról készült radiológiai felvételek az endodonciai kezelést megelőzően és azt követően a) kiindulási periapicalis felvétel a 47-es fogról

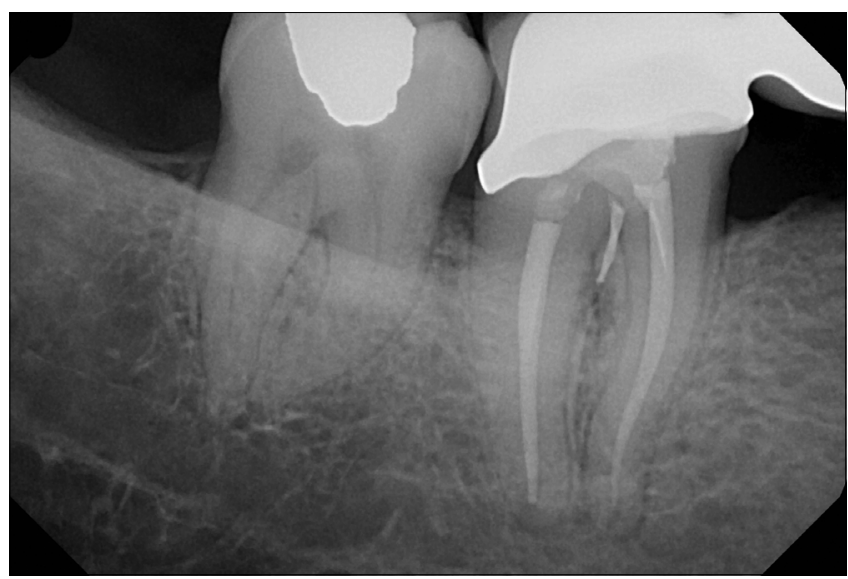

b) egyéves kontroll felvétel a 47-es fogról 


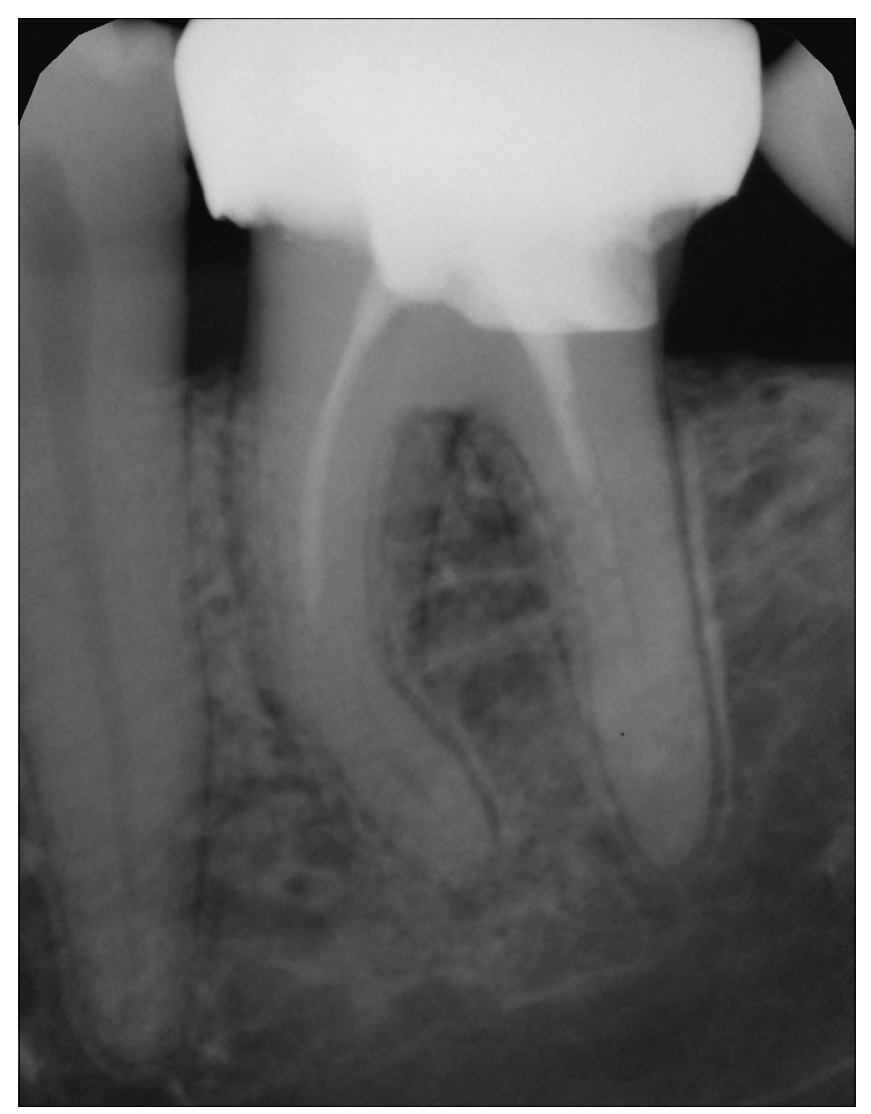

c) kiindulási periapicalis felvétel a 36-os fogról

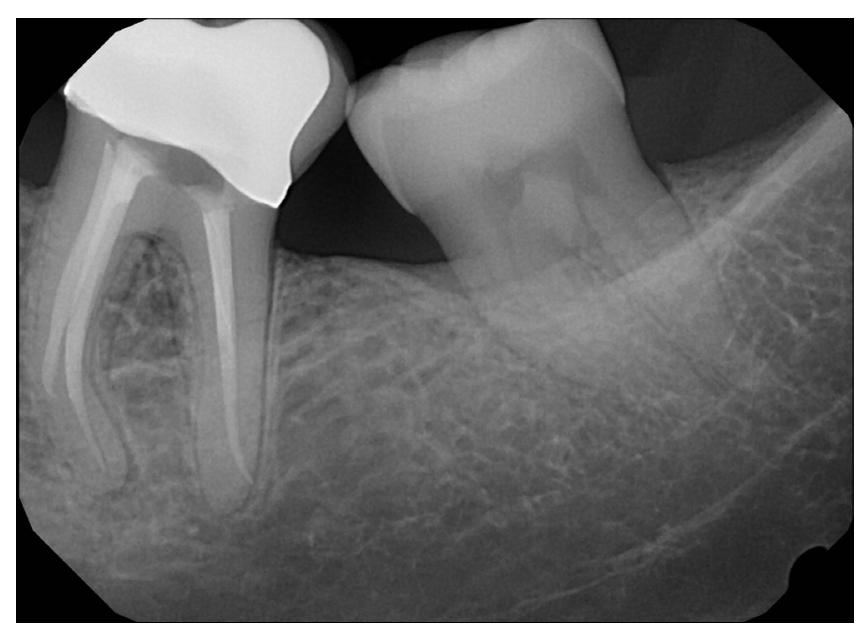

d) egyéves kontroll-felvétel a 36-os fogról

len az elért eredmények fenntartása céljából. Az egyéves kontrollon megjelent páciensről készült klinikai képeken látható, hogy sikerült elsajátítania jó egyéni szájhigiéné fenntartását (14. $a, b, c, d, e$ ábra).

\section{Megbeszélés}

A krónikus parodontitis oka, rizikótényezői és oki kezelési protokollja ismert, nagyszámú eredeti közlemény

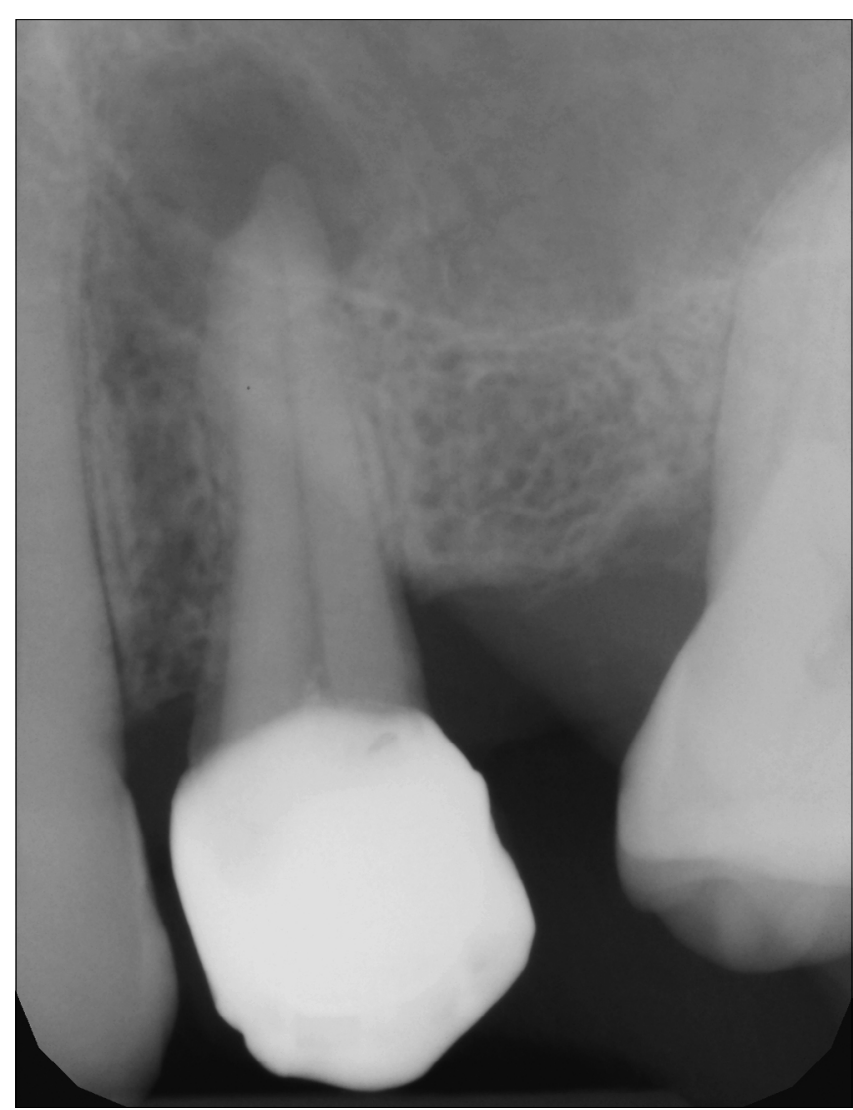

e) kiindulási periapicalis felvétel a 24-es fogról

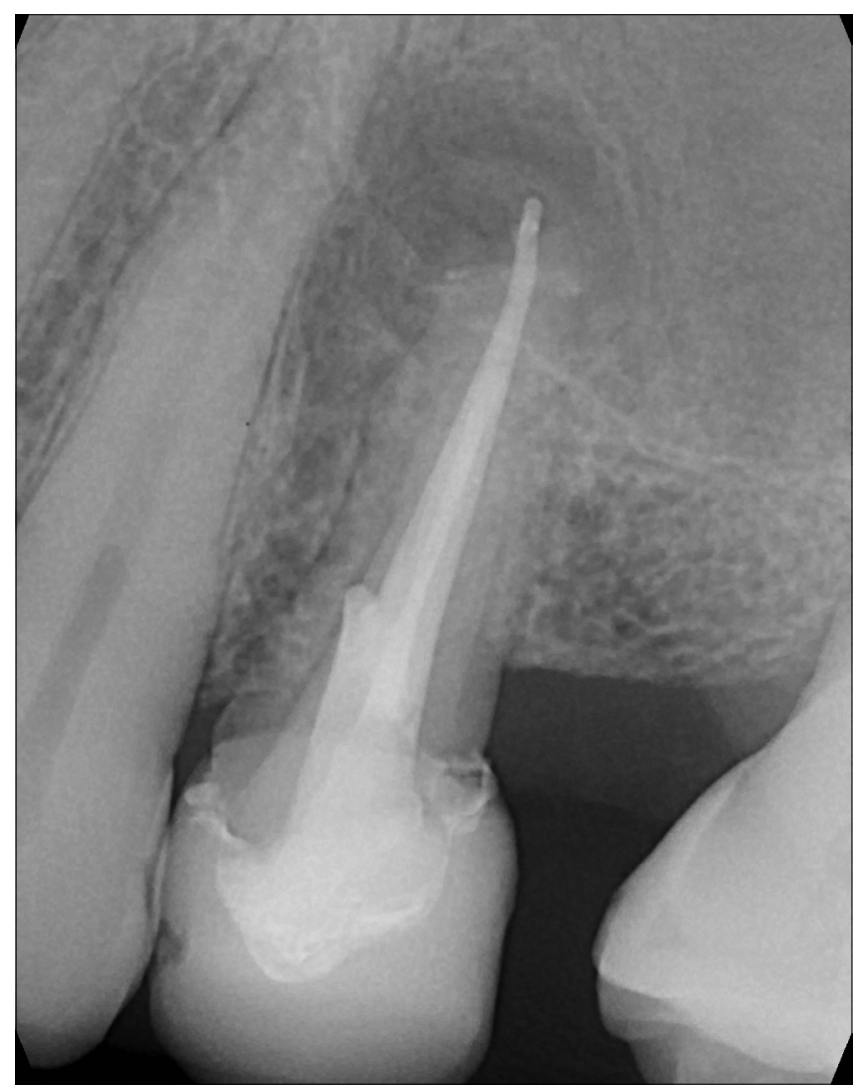

f) kontroll-felvétel a 24-es fogról, közvetlenül a gyökérkezelést követően 
és meta-analízis nyújt támpontot a parodontológusnak a betegség kezelésében és a beteg menedzselésében $[10,12,14,20,22,23]$. A bemutatott komplex esetben nem választható el a nem sebészeti/sebészeti parodontális kezelés a hibás korona-híd munkák korrekciójától, az endodontálisan érintett fogak kezelésétől és végül a protetikai rehabilitációtól. A végleges protetikai kezelés sikere elsősorban a megelőző parodontális kezelés eredményétől és a páciens megfelelő motivációjától, otthoni szájhigiéniás gyakorlatától függ $[12,13,18]$. llyen esetben gyors eredményre nem számíthatunk. Ezért fontos a beteg kellő felvilágosítása már az iniciális kezelés kezdetén, hogy bizony néha egy-másfél év telik majd el addig, mire a várt protetikai rehabilitáció befejeződhet. Nincs olyan oki vagy korrekciós kezelési fázis, amely lerövidíthető vagy elkerülhető lenne. Amennyiben kompromisszumot kötünk annak érdekében, hogy a pótlások hamarabb készüljenek el, akkor a preparációnál, de főleg a lenyomatvételkor nem lesz a marginális parodontium olyan állapotban, hogy precíz és pontos lenyomat és arra nagyon pontosan illesztett para- vagy subgingivalis széli záródású korona készülhessen. Még ma is sokat vitatott, hogy a korona széli zárása sub-, para- vagy supragingivális legyen [9, 16, 34, 35, 36, 41, 42]. Egy krónikus parodontitisben szenvedő páciens, akinél a komplex rizikótényezők miatt alakult ki gyulladás, tasakképződés és tapadásveszteség, mindig is fogékonyabb lesz a dentális plakkakkumulációra és gyulladásos válaszreakcióra, ezért ilyenkor mindig a higiéniát, a fogmű tisztíthatóságát kell szem előtt tartani és legfeljebb csak az esztétikus zónában engedhető meg para, vagy subgingivális széli záródás, egyébként mindig supragingivális széli záródású koronák készítése indikált [26, 44, 45].

Az oki és korrekciós kezelés és protetikai rehabilitáció mellett legalább ilyen jelentősége van az aktív kezelési fázis után a páciens ellenőrzésének és a rendszeres professzionális szájhigiéniás kezelés ütemezésenek [3, 4, 5, 19, 23, 25, 41, 42]. Ma már nagyon sok hosszú távú követéses vizsgálat tanúsítja, hogy a parodontálisan érintett fogakra készült fix fogpótlások élettartama nem rövidebb, mint az ép parodontiumú fogakon elhorgonyzott pótlásoké akkor, ha azok minősége kifogástalan és a supragingivális szájhigiénia tökéletes [31].

\section{Irodalom}

1. Armitage GC: Classifying periodontal diseases - a long standing dilemma. Periodontol 2000. 2002; 30: 9-23.

2. Armitage GC: Development of a classification system for periodontal diseases and conditiions. Ann Periodontol. 1999; 4: 1-6.

3. Axelsson P, LINDHE J: The effect of controlled oral hygiene procedures on caries and periodontal disease in adults. J. Clin. Periodont. 5, 133, 1978.

4. AxELSSON P, LINDHE $\mathrm{J}$ : The significance of maintenanca care in the treatment of periodontal disease. J. Clin. Periodont. 8, 281, 1981.

5. AxelsSon P, LiNDHE J: The long term effect of a plaue control programme on tooth morbidity caries and perioodntontal disease in adults. J. Clin. Periodont. 31, 749-757, 2004.

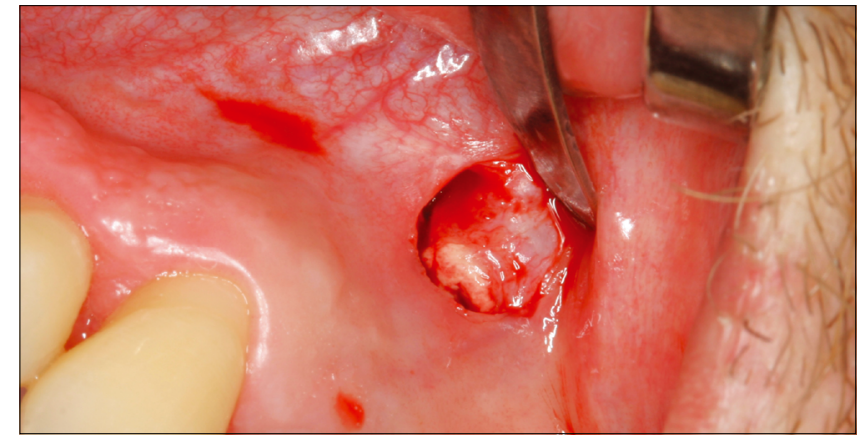

9. ábra: 24-es fog gyökércsúcs rezekciója a) intraoperatív kép a lebenyképzést követően

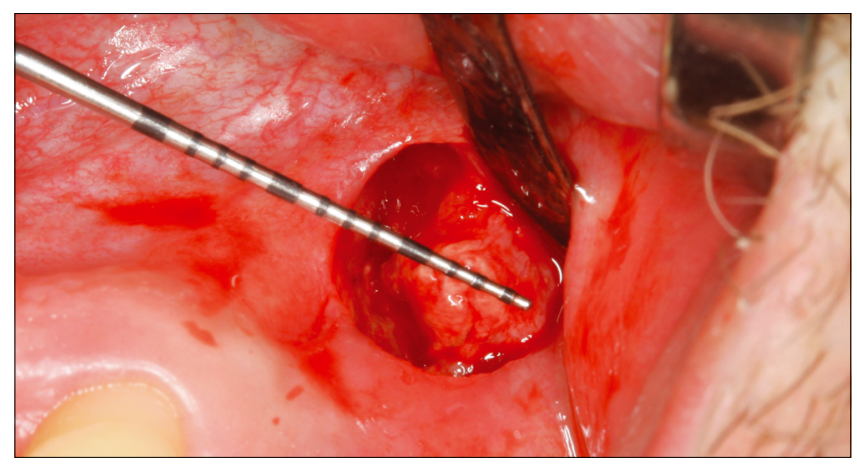

b) a buccalis csontfalat áttört gyulladásos szövetszaporulat terjedelme

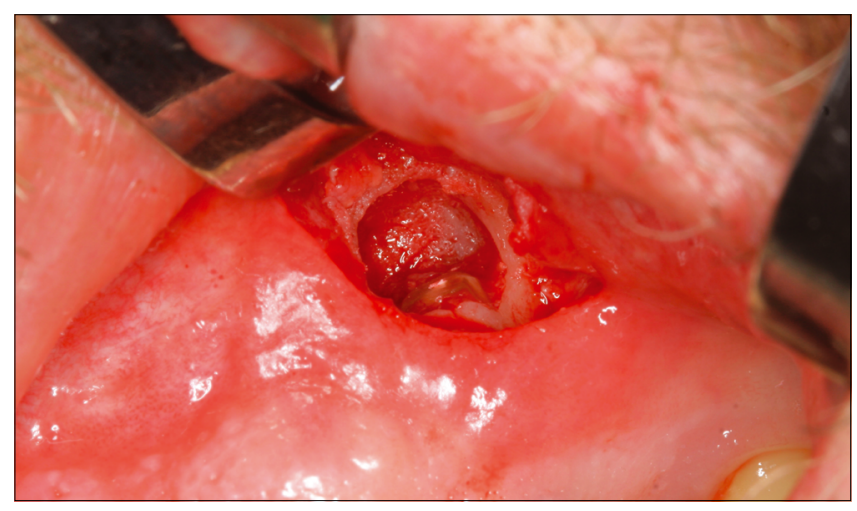

c) a periapicalis térség a gyulladásos szövetszaporulat eltávolítását és a gyökércsúcs rezekcióját követően

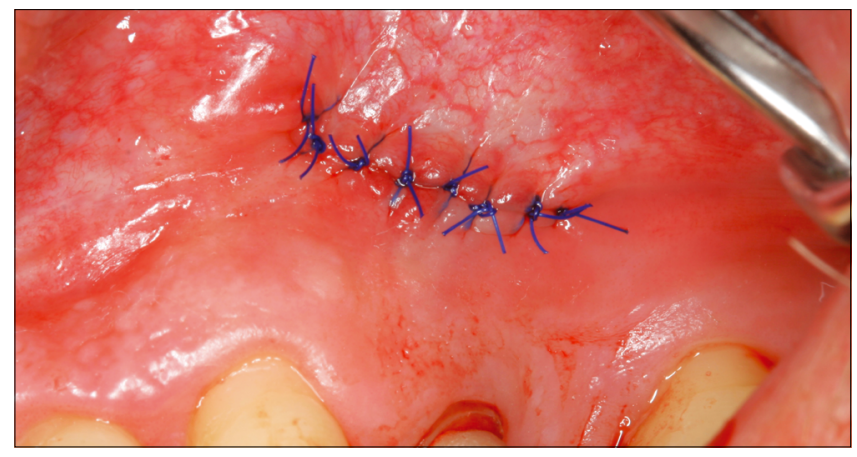

d) sebzárás 


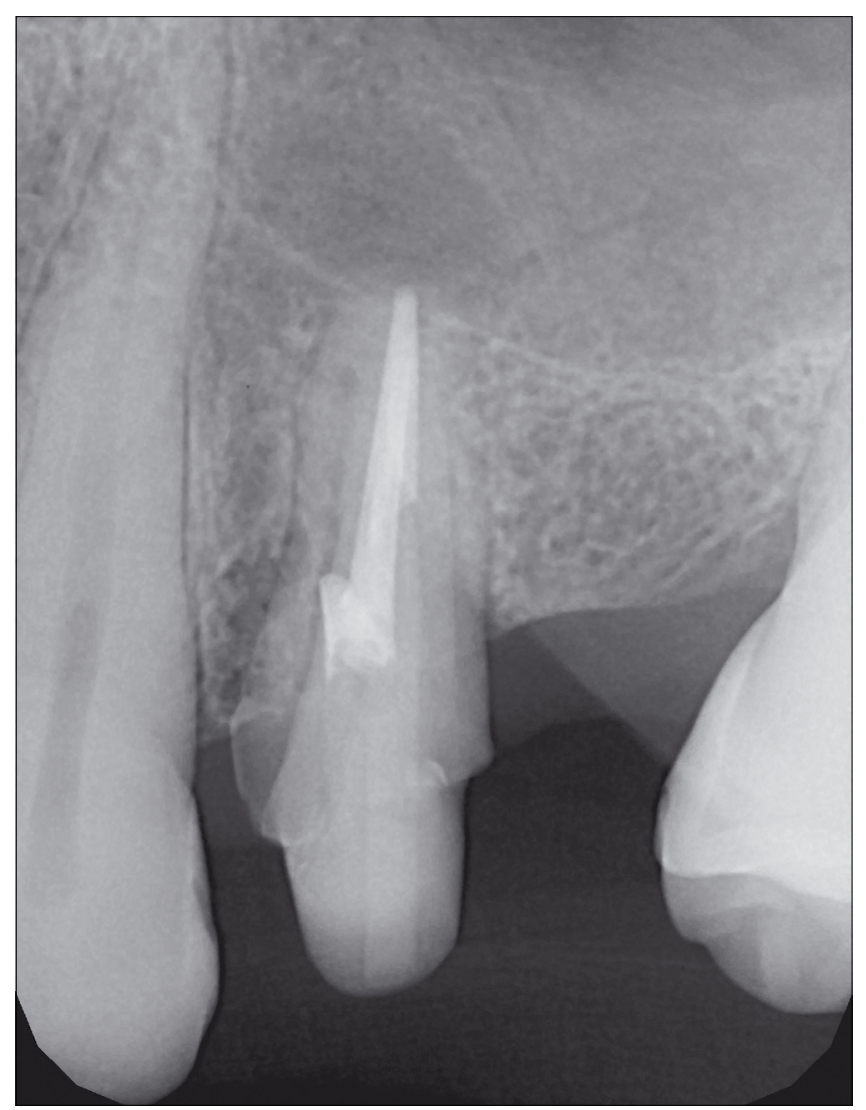

e) kontroll periapicalis felvétel 3 hónappal a mútétet követően

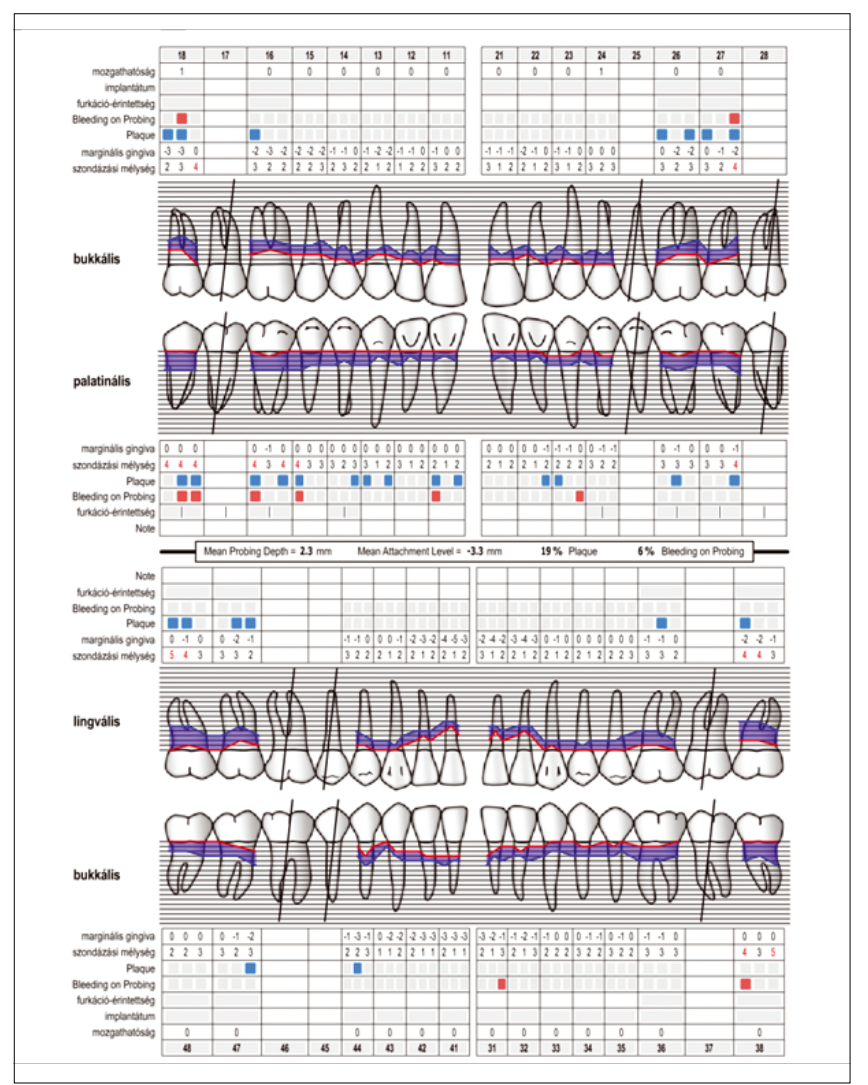

11. ábra: A sebészi terápiát követő kiértékelő parodontális státusz

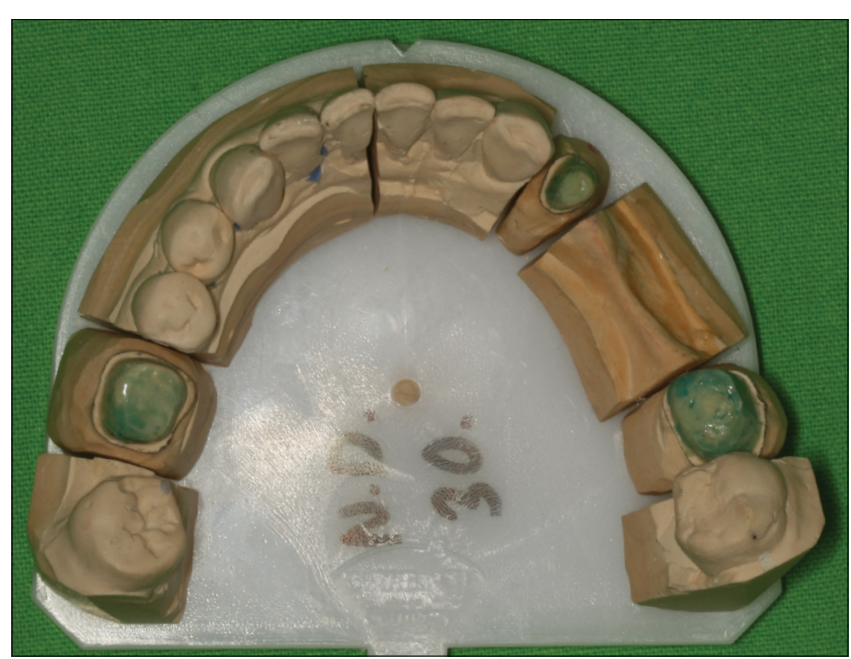

10. ábra: 36, 44, 47-es fogak vállas előkészítése a) az alsó szekciós minta

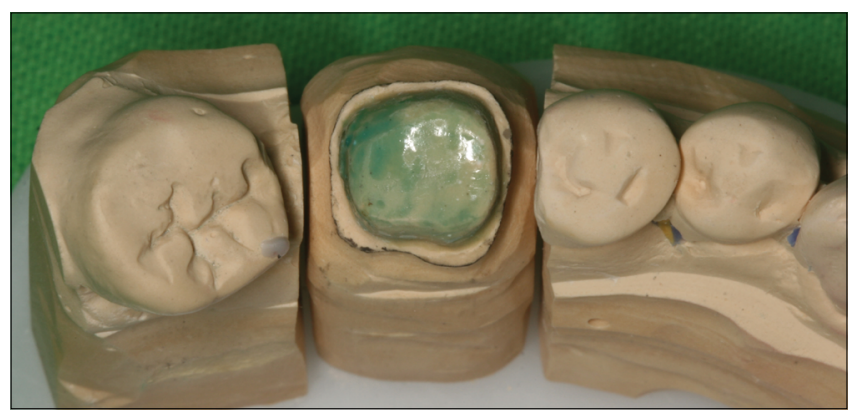

b) a 36-os fog supragingivalis vállas előkészítése

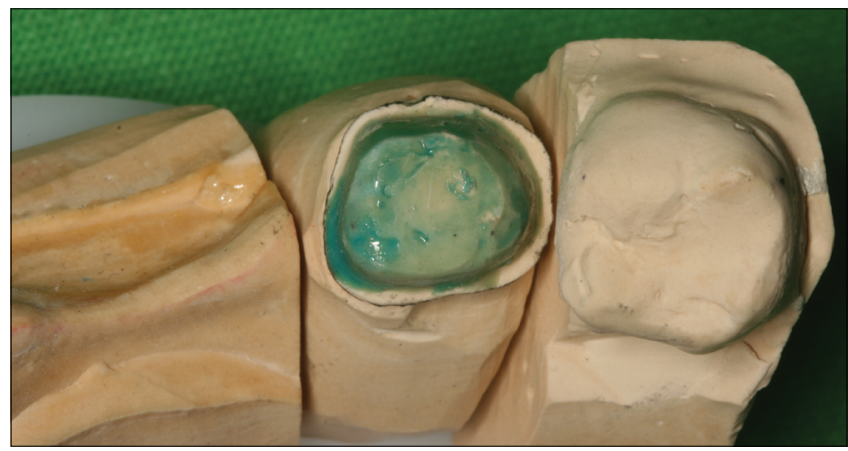

c) a 47-es fog supragingivalis vállas előkészítése

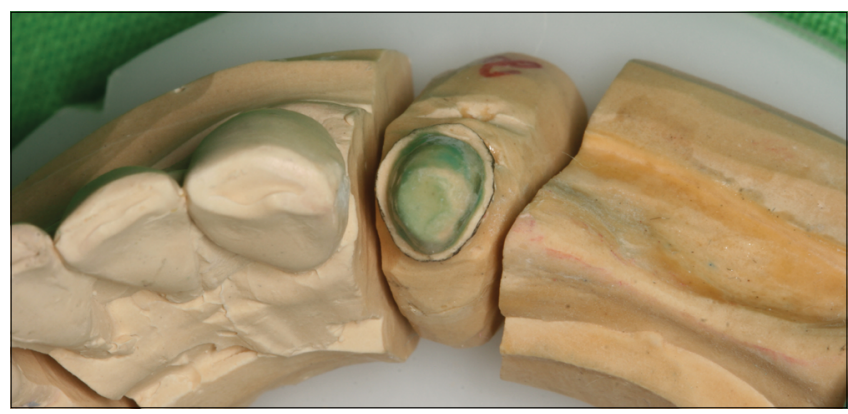

d) a 47-es fog supragingivalis vállas előkészítése 


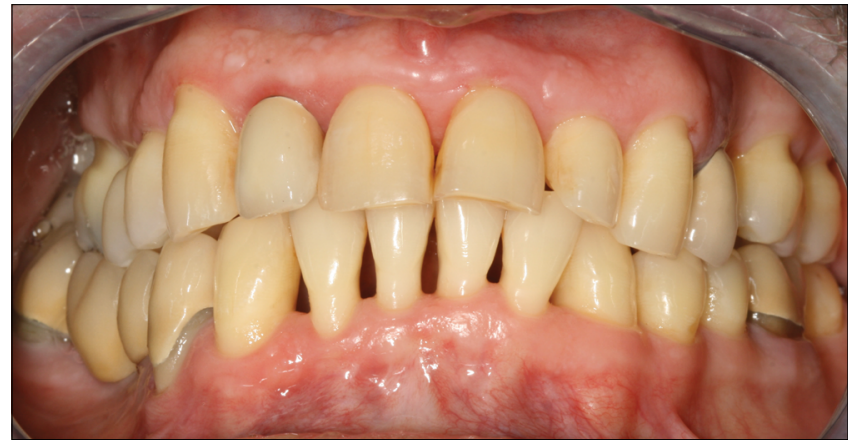

12. ábra: A teljeskörü parodontális és protetikai rehabilitációt követő klinikai képek

a) klinikai kép összezárt helyzetben

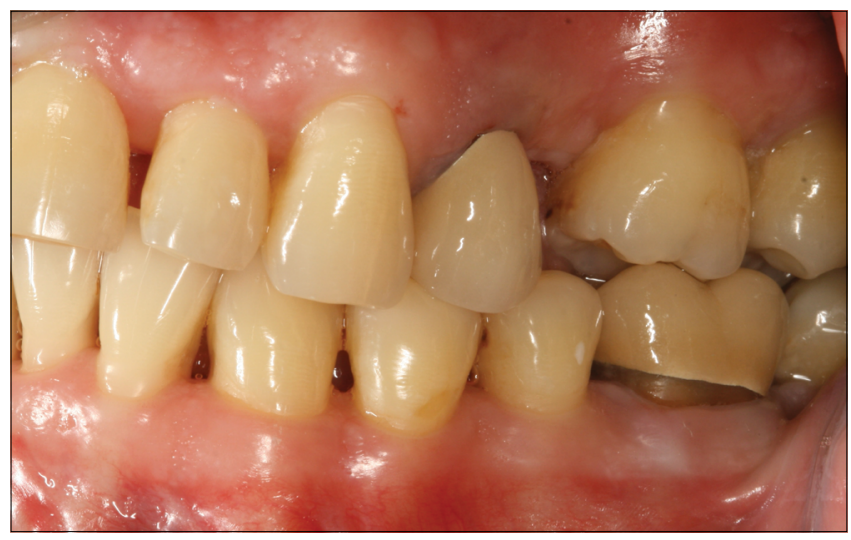

b) bal oldal összezárt helyzetben

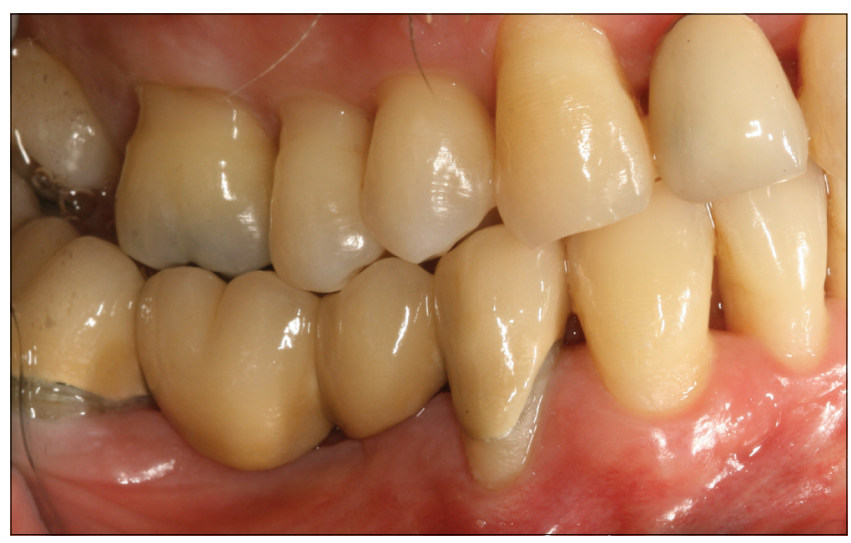

c) jobb oldal összezárt helyzetben

6. Badersten A, Nilveus R, Egelberg J: Effect of non-surgical periodontal therapy. VI. Localization of sites with probing attachment loss. J Clin Periodontol. 1985: 12: 351-359.

7. Badersten A, Nilveus R, Egelberg J: Effect of nonsurgical periodontal therapy. II. Severely advanced periodontitis. J Clin Periodontol. 1984: 11: 63-76.

8. BeIKLER T, FLEMmig TF: Oral biofilm-associated diseases: trends and implications for quality of life, systemic health and expenditures. Periodontology 2000. Vol. 55, 2011, 87-103.

9. BJÖRN AL, BJÖRN H, GROKOVIC B: Marginal fit of restorations and its relation to periodontal bone level. Part one. Metal filings. Odont. Revy. 20, 311, 1969.

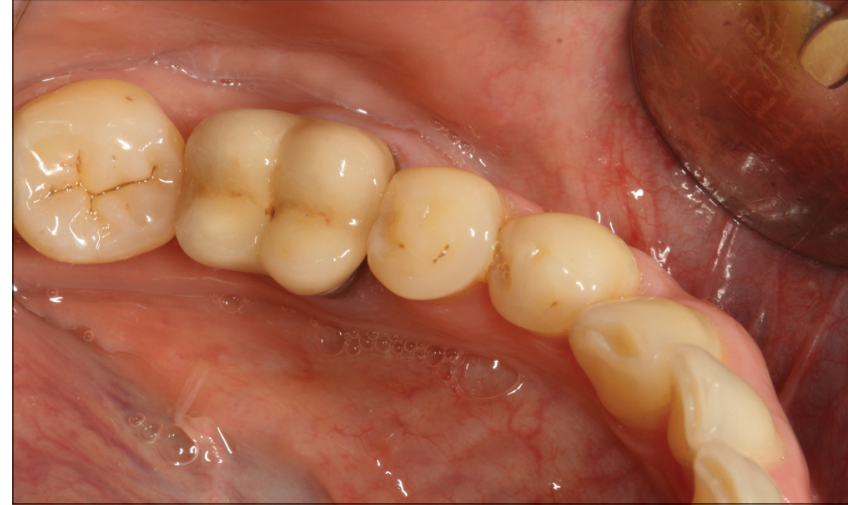

d) alsó fogív bal oldal

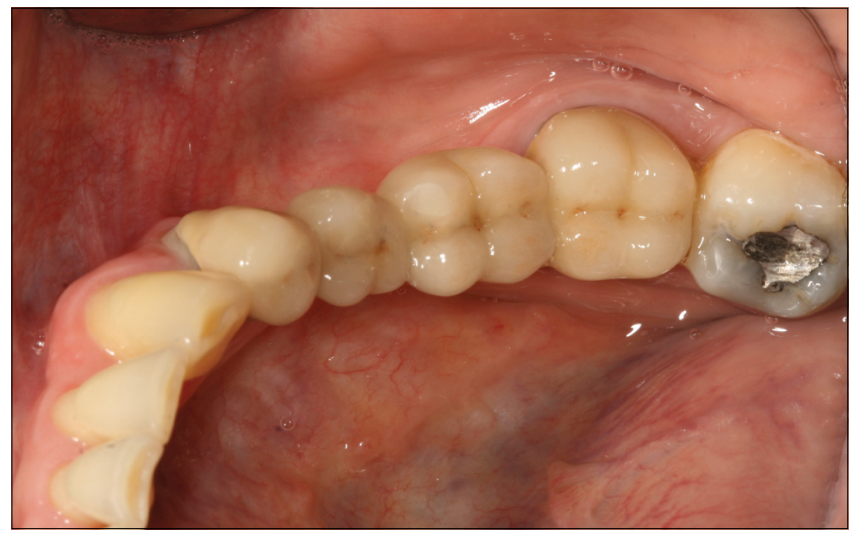

e) alsó fogív jobb oldal

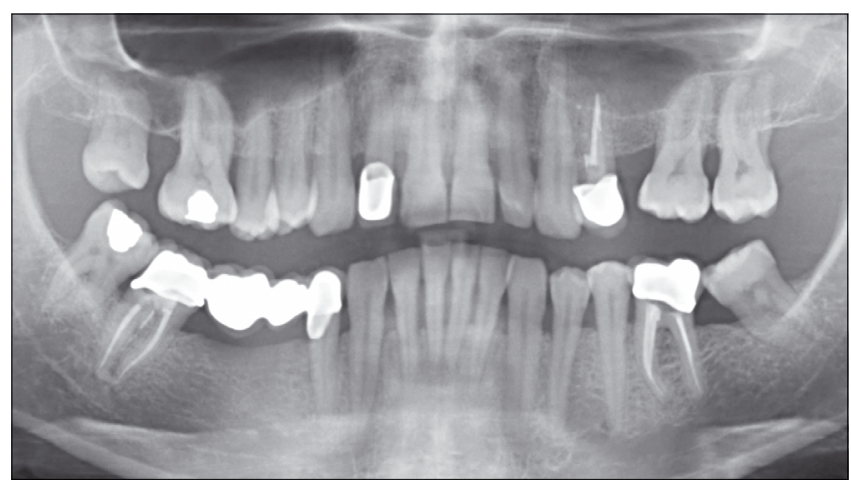

13. ábra: Radiológiai kontroll

a) kontroll OP felvétel

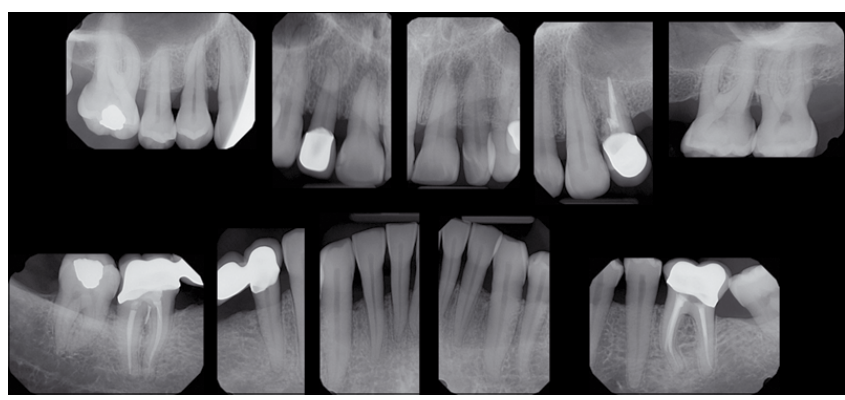

b) kontroll radiológiai státusz 


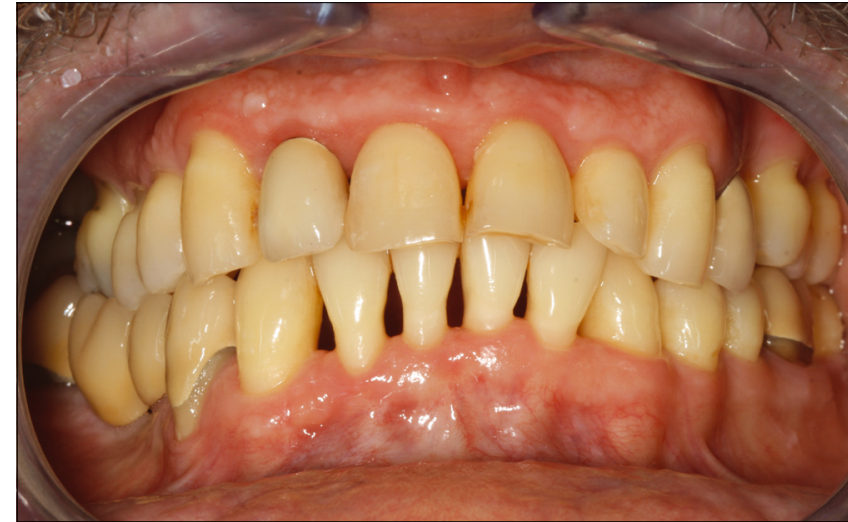

14. ábra: Klinikai képek a kezelés befejezését követően egy évvel: páciens jó szájhigiénét tud fenntartani.

a) klinikai kép összezárt helyzetben

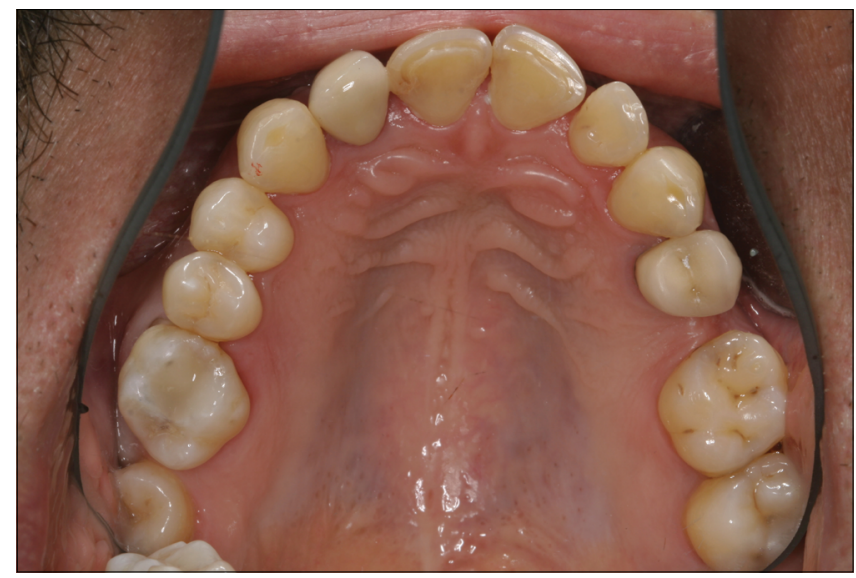

b) felső fogív

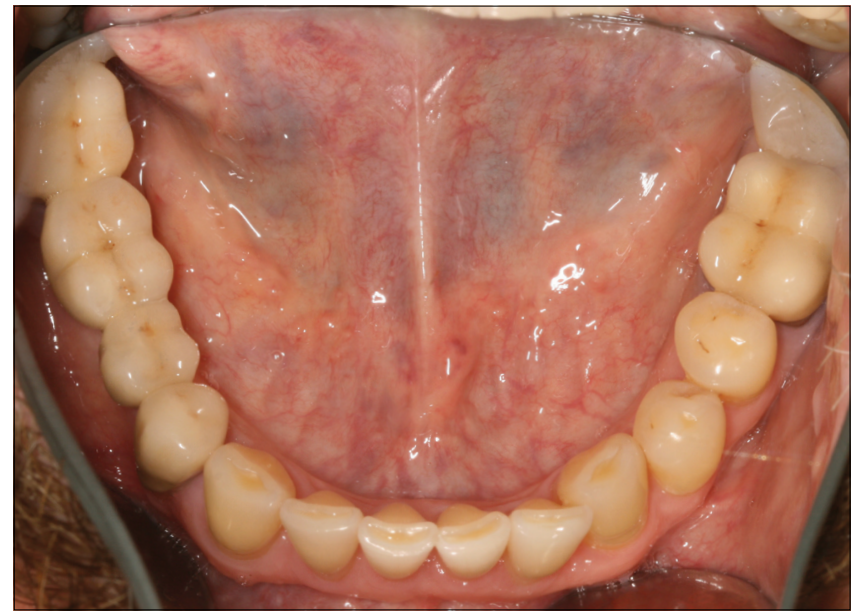

c) alsó fogív

10. Bollen CM, QuiRYNen M: Microbiological response to mechanical treatment in combination with adjunctive therapy. A review of the literature. J Periodontol. 1996: 67: 1143-1158.

11. Carnevale $\mathrm{G}^{1}$, Kaldahl WB: Osseous resective surgery. Periodontol 2000. 2000 Feb; 22: 59-87.

12. Deas DE, Mealey BI: Response of chronic and aggressive peri-

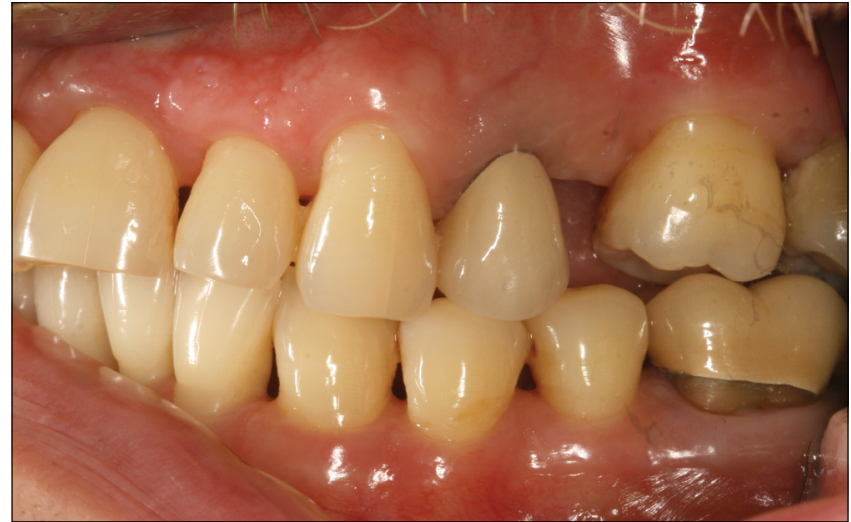

d) bal oldal összezárt helyzetben

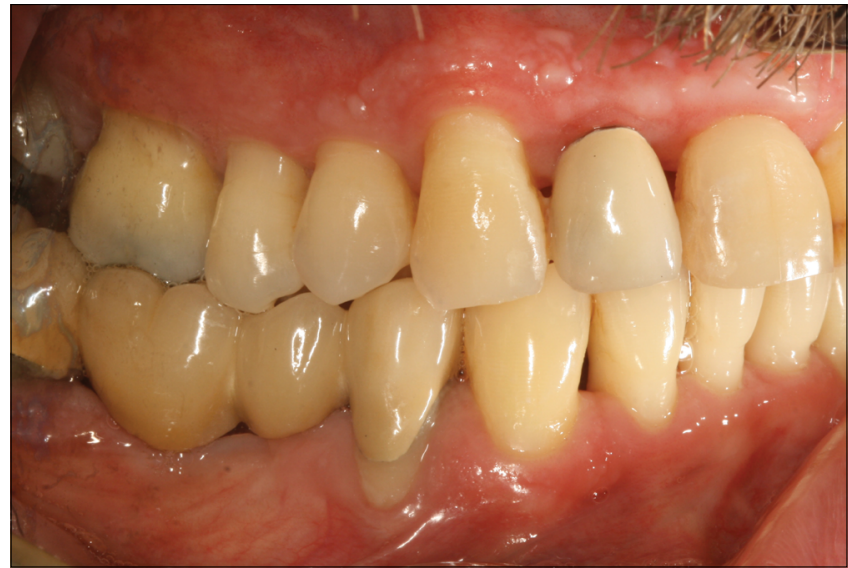

e) jobb oldal összezárt helyzetben

odontitis to treatment. Periodontology 2000. Vol. 53, 2010, 154166.

13. Drisko CH: Nonsurgical periodontal therapy. Periodontol 2000. 2001: 25: 77-

14. Elter JR, Lawrence HP, Offenbacher S, Beck JD: Meta-analysis of the effect of systemic metronidazole as an adjunct to scaling and root planing for adult periodontitis. Periodontal Res. 1997 Aug; 32(6): 487-496.

15. GENCO RJ: Current view of risk factors for periodontal disease. J Periodontol. 67, 1041-1049, 1996.

16. Gera, I (szerk): Parodontológia. Semmelweis Kiadó, 2009.

17. Gilbert AD, NutTALL NM: Self-reporting of periodontal health status. Br Dent J. 1999 Mar 13; 186(5): 241-244.

18. Grosso JE, Nalbadian J, Sanford C, Bailit H: Effect of restorative quality on periodontal health. Journal of Prosthetic Dentistry. 1985; 53: 14-20.

19. Heasman PA, McCracken GI, Steen N: Supportive periodontal care: the effect of periodic subgingival debridement compared with supragingival prophylaxis with respect to clinical outcomes. J Clin Periodontol. 2002: 29 (Suppl. 3): 163-172.

20. Heitz-Mayfield L, Trombelli L, Heitz F, Needleman I, Moles D: A systematic review of the effect of surgical debridement vs. non-surgical debridement for the treatment of chronic periodontitis. J Clin Periodontol. 2002: 29 (Suppl. 3): 92-102.

21. Herrera D, Sanz M, Jepsen S, Needleman I, Roldan S: A systematic review on the effect of systemic antimicrobials as an adjunct to scaling and root planing in periodontitis patients. J Clin Periodontol. 2002: 29 (Suppl. 3): 136-159. 
22. Hung HC, Douglass CW: Meta-analysis of the effect of scaling and root planing, surgical treatment and antibiotic therapies on periodontal probing depth and attachment loss. J Clin Periodontol. 2002: 29: 975-986.

23. ISIDOR F, KARRING T: Long-term effect of surgical and non-surgical periodontal treatment. A 5-year clinical study. J Periodontal Res. 1986: 21: 462-472.

24. JefFCoAt MK, Reddy MS: Progression of probing attachment loss in adult periodontitis.J Periodontol. 1991; 62: 185-189.

25. Kaldahl WB, Kalkwarf KL, Patil KD, Molvar MP, Dyer JK: Longterm evaluation of periodontal therapy. I. Response to 4 therapeutic modalities. J Periodontol. 1996: 67: 93-102.

26. LANG NP, TONETTI MS: Periodontal risk assessment for patients in supportive periodontal therapy (SPT). Oral Health and Preventive Dentistry. 2003; 1: 7-16.

27. LANG PN, KIEL AR: Anderhalden: Clinical and microbiological effects of subgingival restorations with overhangings or clinically perfect margins. J. Clin Periodontol. 1983; 10: 563-578.

28. LindHE J, NymAN S: Scaling and granulation tissue removal in periodontal therapy. J Clin Periodontol. 1985: 12: 374-388.

29. Lindhe J, Westrelt E, Nyman S, Socransky SS, Heisl L, Bratthall G: Healing following surgical/non-surgical treatment of periodontal disease. A clinical study. J Clin Periodontol. 1982: 9: 115-128.

30. LISA J. HeitZ-MAYField L: How effective is the surgical therapy compared with non-surgical therapy. Periodontology 2000. 2005; $37 ; 72-87$.

31. Lundgren D, Nyman S, HeiJl L, Carlsson GE: Functional analysis of fixed bridges on abutment teeth with reduced periodontal support. J Oral Rehabil. 1975: 2: 105-116.

32. Pihlstrom Bl, Mchugh RB, Oliphant TH, Ortiz-Campos C: Comparison of surgical and non-surgical treatment of periodontal disease. A review of current studies and additional results after $61 / 2$ years. J Clin Periodontol. 1983: 10: 524-541.

33. RamfJord SP, Nissle RR: The modified Widman flap. J Periodontol. 1974 ; 45: 601-607.
34. Renggli HH, Regolatı B: Gingival inflammation and plaque accumulation by well-adapted supra-and subgingival proximal restorations. Helv. Odont. Acta. 1972; 99: 16-23.

35. SILNESS J: Periodontal conditions in patients treated with dental bridges. III. The relationship between the location of the crown margin and the periodontal condition. J Periodontal Res. 1970: 5: 225-229.

36. Socransky S, Haffajee A: The bacterial aetiology of destructive periodontal disease: current concepts. J Periodontol. 1992: 63: 332-331.

37. Socransky SS, Haffajee AD: Periodontal microbial ecology. Periodontology 2000. I. 38, 2005, 135-187.

38. Stewart Jl, Gratzel K, Gerity EJ, Akerman M, Hill JM: Comparison of soft toothbrush and new ultra-soft cleaner in ability to remove plaque from teeth. N Y State Dent J. 2014 Nov; 80(6): 28-32.

39. Suvan J: Effectiveness of non-surgical pocket therapy. Periodontology 2000. 2005; 37; 48-71.

40. Tunkel J, Heinecke A, Flemmig TF: A systematic review of efficacy of machine-driven and manual subgingival debridement in the treatment of chronic periodontitis. J Clin Periodontol. 2002: 29 (Suppl. 3): 72-81.

41. Valderhaug J, Heloe L: Oral hygiene in a group of supervised patients with fixed prosthesis. J Periodontol. 1977: 48: 221-224.

42. Valderhaug J: Periodontal conditions and carious lesions following the insertion of fixed prostheses: a 10-year follow-up study. Int Dent J. 1980: 30: 296-304.

43. Van der WeiJden GA, Timmerman MF: A systematic review on the clinical efficacy of subgingival debridement in the treatment of chronic periodontitis. J Clin Periodontol. 2002: 29 (Suppl. 3): 55-71.

44. WAERHAUGH J: Effect of rough surfaces upon gingival tissue. J.Dent Res. 1956; 35: 323-325.

45. WAERHAUGH J: Histologic considerations which govern where the margins of restorations should be located in relation to the gingiva. Dent. Clin. North A. 1960; 4: 161-176.

\section{Pilihaci Bella, Gera István}

\section{The comprehensive periodontal, resorative end prosthodontic therapy of chronic periodontitis Case presentation}

Chronic periodontitis predictable responds to mechanical cleaning and cause related periodontal surgery. Nowadays the therapeutic protocol of the chronic periodontitis is widely known and scientifically proven. The therapy can be split into two major phases, the inicial or cause related therapy and the surgical therapy, however in the most of the cases the patients need complex periodontal, restorative and prosthodontic therapy. The presented case demonstrates the process and results of the complex treatment of a 55 years old patient suffering from chronic periodontitis. The patient didn't have hopeless teeth. In the first phase of the cause related periodontal therapy professional oral hygiene treatment, scaling rootplaning and subgingival curettage were performed by quadrants. At the re-evaluation after the conservative periodontal therapy there was a significant pocket reduction in the mandibular quadrants, however there was a need for surgical pocket therapy in the molar regions of the maxillary quadrants. Modified Widman-flap surgery and osteoplasty were performed in both of the maxillary quadrants. After the surgical periodontal therapy the revision of the old root canal fillings was accomplished in the teeth 24,36 and 47 . Due to an inflammatory root resorption, root resection was performed following the root canal filling on the tooth 24 . Three months after the root resection surgery, the tooth was reinforced by a glass fiber post. Nine months postoperatively the periapical area of the tooth 24 showed growing radioopacity After the second reevaluation of patient's compliance and the healing tendencies full mouth prosthodontic reheabilitation was provided. Metalloceramic crowns with a supragingival margin were made on the teeth 12,24 and 36, metalloceramic bridge was made on the teeth 44 and 47 . After the periodontal, restorative and prosthodontic therapy were finished the patient was remanded every 3 months for periodontal supportive therapy and could maintain excellent oral hygiene with a plaque score under $20 \%$ and a bleeding score of $6 \%$.

Key words: chronic periodontitis, non-surgical pocket therapy, periodonto-endodontic-prosthodontic therapy, modified Widman flap, supportive therapy 